РОЗВИТОК ПРОФЕСІЙНОÏ КОМПЕТЕНТНОСТІ ОФІЦЕРІВ

ІНФОРМАЦІЙНО-АНАЛІТИЧНОГО ЗАБЕЗПЕЧЕННЯ

ОПЕРАТИВНО-ТАКТИЧНОГО РІВНЯ

ЯК ПСИХОЛОГО-ПЕДАГОГІЧНА ПРОБЛЕМА

\title{
DEVELOPMENT OF PROFESSIONAL COMPETENCE OF FURTHER INFORMATIONAL-ANALYTICAL ASSISTANCE OFFICERS AS A PSYCHOLOGICAL-PEDAGOGICAL PROBLEM
}

У статmі проаналізовано проблему фрормування та розвитку просресійної компетентності офріцерів інформаційно-аналітичного забезпечення як військових фрахівців у психологічній і педагогічній науках. Теоретичне обгрунтування проблеми здійснено з урахуванням специсріки реалізації посадових обов'язків офрічерів інфрормаційно-аналітичного забезпечення, а також дослідницьких завдань, які поставлені у науковій роботі. Вона розглядається як система науково сорормованих правил $і$ прийомів навчання. Автор також зазначає, що концепція дослідження забезпечується єдністю теоретичного, методологічного та методичного аспектів. Зокрема на основі опрацювання психолого-педагогічної літератури ним здійснено розәляд проблеми компетент ності орахівців інфоормаційно-аналітичного забезпечення в наукових працях як закордонних, так і вітчизняних дослідників з урахуванням вимог сучасних методологічних підходів до підготовки спеціалістів, закономірностей фрункціонування людської психіки в екстремальних ситуаціях. Визначено основні аспекти обгрунтування профресійної компетентності військових фрахівців. Простежено характеристики спеціальноі квалісрікації офріцерів інорормаційно-аналітичного забезпечення, які потрібно розвивати для досягнення професіоналізму при здійсненні військової діяльності. Досліджено структуру спеціальної обізнаності офріцерів інфрормаційно-аналітичного забезпечення згідно з вимогами андрагогічного, контекстного, компетентнісного та суб'єктнодіяльнісного підходів до їх професійної підготовки на етапі оперативно-тактичного рівня освіти у Національному університеті оборони України імені Івана Черняховського. Автор на основі проведення наукових підходів зробив висновок, що, зокрема, професійна компетентність офріцерів інфоомаційно-аналітичного забезпечення включає такі компоненти: ціннісно-мотиваційний, емоційно-вольовий, когнітивний, операційнопрочесуальний, психологічний чи фраховий, важливий професійно-якісний індивідуальнопсихічний, суб'єктний.

Ключові слова: компетентність, професійна компетентність, структура просе- сійної компетентності, офріцери інфрормачійно-аналітичного забезпечення.

An author analyzes a problem of formation and development of professional competence of informational and analytical assistance officers, as military specialists in the psychological and pedagogical sciences. The theoretical substantiation of this technique is made taking into account the specifics of realization of job competencies of informational and analytical assistance officers, as well as the research tasks that are established in the scientific research. It is considered as a system of science-based rules and techniques of training. The author also notes that the concept of the research is ensured by the unity of theoretical and methodological aspects. In particular, on the basis of the analysis of psychological and pedagogical literature, the analysis of the problem of competence of specialists in scientific works of both foreign and domestic researchers, taking into account the requirements of modern methodological approaches to the training of specialists, patterns of functioning of the human psyche in extreme activity situations. The main aspects of substantiation of professional competence of military specialists are determined. The characteristics of the professional competence of informational and analytical assistance officers, which need to be developed in order to achieve professionalism in the exercise of military and professional activity, are considered. The structure of professional competence of informational and analytical assistance officers according to the requirements of contextual, competence and subject-activity approaches to their professional training at the stage of operational and tactical level at Ivan Chernyakhovsky National Defense University of Ukraine is substantiated. The authors also concluded, based on scientific approaches, that, in particular, the professional competence of the organizers of moral and psychological support includes the following components: emotional-volitional, cognitive, operational-procedural, psychological or professional, individually-psychic, subjective. Key words: competence, professional competence, structure of professional competence, informational and analytical assistance officers.
Постановка проблеми. Офріцер інфрормаційноаналітичного забезпечення (далі - IA3) - це фрахівець, який готує вихідні дані для прийняття рішення командиром. Водночас він сам є командиром для своїх безпосередніх підлеглих. Від нього і його підлеглих залежить якість вироблення замислу операцій (бойових дій). Це досягається за рахунок здобуття, оброблення та своєчасної підготовки необхідних даних, зниження часу проведення опе- ративно-тактичних розрахунків, розроблення та оцінювання декількох варіантів рішення. Якісне управління бойовою діяльністю військ в цих умовах стає вирішальним чинником досягнення успіху в збройній боротьбі. Це накладає на офріцера IA3 велику відповідальність не тільки за зміст і результати власної професійної діяльності, а й за процес перероблення інформації про обставини і умови фрункціонування об'єктів у команди (параметри), 
які забезпечують або збереження стану об'єктів, або приведення їх до іншого стану відповідно до заданої мети. Безпосередньо хід управління може розглядатися як інорормаційний процес, в якому збір, оброблення, збереження і передача інфрормації займає надзвичайно важливе місце.

В умовах, коли орган управління працює в дефіциті часу й зростає ціна рішень, що ним приймаються, важливим стає визначення заходів щодо інтенсифрікації його роботи, підвищення ефективності фрункціонування. Одним із способів продуктивного виконання складних завдань управління $€$ створення системи IA3, першочерговим призначенням якої $є$ цілеспрямоване задоволення інфрормаційних потреб та підтримка логіко-аналітичної діяльності посадових осіб органів військового управління. За даних умов зростає роль фрахової компетентності офріцера ІАЗ як офріцера-аналітика, так і як офріцера-командира.

Аналіз досліджень. Проблема розвитку профресійної компетентності у офріцерів IAЗ оперативно-тактичного рівня досить актуальна та багатоаспектна, а іії змістовне поле знаходиться на стику педагогіки, фрілософії, інорорматики, логіки, психології та військової справи. Проблему професійної компетентності фрахівців у різних аспектах досліджують як зарубіжні (К. Вуоно, Дж. Равен, С. Паррі Сем С. Саркесьян, Р. Уайт), так і вітчизняні (В. Андрущенко, Г. Артюшин, В. Баркасі, О. Бойко, А. Вітченко, А. Галімов, О. Діденко, С. Желтобрюх, А. Зельницький, В. Король, В. Кремень, Т. Мацевко, Н. Ничкало, Ю. Приходько, В. Радкевич, В. Свистун, Т. Сорочан, О. Торічний, В. Ягупов та інші) науковці. Водночас узагальнення праць цих та інших вчених показує, що проблема професійної компетентності офріцерів ІАЗ оперативнотактичного рівня, тобто в системі післядипломної освіти, є недостатньо дослідженою.

Мета статті - проаналізувати проблему професійної компетентності військових фрахівців у психолого-педагогічній літературі та визначити їі структуру в офріцерів ІАЗ оперативно-тактичної ланки управління.

Виклад основного матеріалу. Застосування військових підрозділів і частин у бойових діях це явище багатомірне, системне, суперечливе і $\epsilon$ таким збігом різноманітних позитивних і, насамперед, негативних обставин, які виражаються в особливих, несприятливих умовах їх бойової діяльності. Крім того, фрахівці ІАЗ $€$ першочерговою ціллю ворожих сил і засобів інформаційно-психологічних операцій. У зв'язку з цим їхня діяльність характеризується постійною наявністю небезпеки для життя і здоров'я, готовністю до застосування та власне застосуванням зброї, на них діє вороже оточення, інфрормаційний тиск неприязних сил і засобів інорормаційно-психологічних операцій; великими фрізичними навантаженнями у поєднані
3 високою активністю когнітивної сфери; підвищеною концентрацією уваги; підпорядкуванням всього режиму життєдіяльності вирішенню поставленого бойового завдання, що призводить до порушення режиму відпочинку, сну, харчування, дискомфортних санітарно-гігієнічних умов тощо.

У діяльності фрахівців ІАЗ ці характеристики зумовлюють необхідність специфічного підходу до вирішення професійних завдань, мобілізації зовнішніх і внутрішніх резервів, які б дозволили виконувати бойові завдання на межі своїх фрізичних і когнітивних можливостей. Їхня спеціальна діяльність має особливий характер, який водночас має багатоаспектний зміст - педагогічний, психологічний i, безпосередньо, військовий, а фрахова компетентність з урахуванням цілей, завдань, значення і результатів діяльності має продемонструвати інтегровану здатність оперативно та професійно діяти в межах прав як аналітику, офіцерові оперативно-тактичної ланки управління та власне військовослужбовцю. Офріцери ІАЗ розв'язують різноманітні та неоднозначні фрахові завдання. Аналіз їхніх фрункціональних обов'язків і змісту діяльності свідчить про те, що вони, як офріцерикомандири, відповідають за виховання і навчання своїх підлеглих у широкому сенсі; водночас концентрують і зосереджують змістовні психологічні сили, оскільки мають бути одночасно психологами, вихователями, наставниками у фаховій діяльності; і нарешті, характер завдань, які вони виконують як в мирний, так і в воєнний час, вимагають від них військово-профресійної компетентності [1, с. 183], яка забезпечує основу реалізації цих фрункцій.

Вирішенням такого інтегрального завдання займається система військової освіти, що здійснюється на етапі оперативно-тактичного рівня підготовки у Національному університеті оборони України імені Івана Черняховського (далі - НУОУ). У контексті освіти фрахівця-аналітика навчальновиховний процес має бути зорієнтований на забезпечення умов для їх професійного розвитку й саморозвитку. Держава має створювати необхідні умови для їхнього становлення як спеціалістів, які мають високий рівень військово-професійної та, найголовніше, фрахової компетентності.

Якість вищої військової освіти пов'язана насамперед із здобуттям певних професійних знань і вмінь, що дають змогу майбутнім офіцерам оперативно-тактичного рівня, у тому числі й фрахівцям IA3, оптимально використовувати накопичений освітній капітал у реальних умовах військовопрофесійної діяльності. Сьогодні їхня компетентність і професіоналізм виступають головними чинниками військово-професійної самореалізації. що ж таке «профресійна компетентність» як поняття 3 точки зору психолого-педагогічного тлумачення? Проведений аналіз наукових джерел показує, що в сучасній педагогіці та психології 
існують різні погляди щодо визначення процесу формування і розвитку професійної компетентності майбутніх фрахівців. Проте ці погляди базуються на підґрунті психології професії, урахуванні індивідуально-психічних особливостей фрахівця у різних видах діяльності, аналізі умов і чинників розвитку вмінь і навичок у спеціальній практиці, закономірностях розвитку профресіоналізму тощо. Отже можна зазначити, що процес формування/ розвитку профресійної компетентності офріцерів IA3 оперативно-тактичного рівня відбувається в контексті особливої підготовки, зумовлюється вимогами безперервної освіти, розвитком і саморозвитком, здійснюються логічно, взаємопов'язано, поетапно в межах освітнього процесу.

Розглянемо процес розвитку профресійної компетентності майбутніх офріцерів IAЗ на етапі отримання оперативно-тактичного рівня підготовки. Використання терміну «розвиток» у цьому випадку $€$ доречним, адже добір слухачів на навчання здійснюється 3 урахуванням ступені їхньої підготовленості на тактичному рівні. Отже в освітньому процесі відбувається не лише розвиток вже попередньо отриманої профресійної компетентності, а й виведення її на новий рівень - магістерський. Таким чином, ми розглядаємо «розвиток професійної компетентності майбутніх офріцерів IAЗ оперативно-тактичного рівня» як педагогічно керований процес, метою якого $€$ набуття слухачами необхідного рівня розвиненості фахової кваліфікації.

Підсумок аналізу наукових розвідок з питань організації освітнього процесу у воєнному вищому навчальному закладі (далі - ВВН3) дає змогу пов'язати результативність розвитку професійної компетентності офріцерів IАЗ як з психолого-педагогічними аспектами побудови освітнього процесу, так і з ресурсними (матеріально-технічними) можливостями НУОУ.

Розглянемо зміст професійної компетентності офріцерів IA3. Сам термін «професійна компетентність» складається 3 двох категорій - «професія» і «компетентність». Профресія (від лат. professio офріційно вказане заняття) - вид трудової діяльності фрахівця, який володіє комплексом теоретичних знань і практичних навичок і вмінь, отриманиху результаті спеціальної підготовки і досвіду роботи. Наукова дефрініція «профресійна компетентність» у педагогічній літературі трактується як єдність теоретичного та практичного видів підготовки майбутніх фрахівців, знань з особливо важливими якостями, які актуалізуються в майбутній спеціальній діяльності. Для трактування поняття «профресійна компетентність майбутнього офріцера IA3 оперативно-тактичного рівня» доцільно спиратися на зміст і сутність таких ключових понять, як «компетентність», «професіоналізм», «специсріка профресійної діяльності офріцерів IAЗ».
С. Гончаренко термін «компетентність» визначає як сукупність знань і вмінь, необхідних для ефективної спеціальної практики: вміння аналізувати, передбачати наслідки професійної діяльності, використовувати інсрормацію [2, с 49].

Досить актуальним є, на нашу думку, погляд на сутність зазначеного наукового терміну О. Овчарука: компетентність виступає логічною похідною від ставлень до цінностей і сфрормованості умінь у майбутнього фрахівця. Автор опирається на трактування, запропоноване Міжнародним департаментом стандартів для навчання, досягнень та освіти: компетентність як спроможність кваліфріковано провадити діяльність, виконувати завдання або роботу [3, с. 6-15]. Компетентність під таким кутом зору містить сукупність знань, навичок i ставлень, що дає змогу фахівцю ефективно діяти та виконувати певні фрункції, які спрямовані на досягнення постійних стандартів у професійній галузі чи деякій діяльності.

Міжнародним департаментом стандартів для навчання компетентність розглядається як здатність кваліфіковано здійснювати діяльність, виконувати завдання або роботу (International Board of Standards for Training, Performance and Instruction (IBSTPI)). Водночас поняття «компетентність» містить сукупність профресійних знань, навичок i ставлень, що дає змогу фрахівцю ефективно працювати або виконувати певні функції, спрямовані на досягнення стандартів у професійній галузі або діяльності [4].

Звернемося до трактування терміна «компетентність» зарубіжними фахівцями. Так, К. Вуоно визначає сутність компетентності військового керівника як досконале знання своєї справи [5]. С. Валде вважає, що компетентність - це особистісна характеристика, сукупність інтеріоризованих мобільних знань, умінь, навичок і глибокого мислення [6]. Дж. Равен у зміст поняття «компетентність» вкладає специфічну здатність людини, необхідну для есрективного виконання конкретної діяльності в певній предметній галузі. Така здатність передбачає наявність таких якостей, рис і здібностей, як вузькоспеціальні знання, особливі предметні навички, способи мислення, розуміння відповідальності за свої дії [7].

Сем С. Саркесьян обґрунтовує компетентність у галузі безпеки держави та зауважує, що вона означає широту мислення, яка не обмежена військовими міркуваннями та дає змогу ураховувати різні соціальні й політичні наслідки рішень і правильно розуміти необхідність першочергового вирішення питань [8].

Наукове уточнення поняття «компетентність» військового фрахівця уможливило В. Свистун запропонувати своє бачення його сутності як новоутворення, що в процесі формування і розвитку набуває внутрішньої визначеності й стає якістю 
особистості, яка в ході опанування військово-професійною діяльністю стає суб'єктом цієї роботи й в процесі підготовки до виконання завдань набуває здатності ефрективно виконувати спеціалізовані фрункції [9, с. 154-158].

В. Ягупов зазначає, що поняття «компетентність» характеризує якісний стан підготовленості фахівця, який дає змогу отримати відповідну посаду; вона набувається в процесі отримання спеціальної освіти та стосується конкретної особи як майбутнього суб'єкта професійної діяльності. Компетентність розглядається як підготовленість (теоретична та практична) і здатність (інтелектуальна, діяльнісна та суб'єктна), а також готовність (професійна, особистісна, психологічна тощо) особи як фахівця до певного виду особливої діяльності [10, с. 3].

О. Торічний безпосередньо пов'язує професійну компетентність майбутнього офріцера із поняттям «кваліфікація». Він стверджує, що спеціальна кваліфікація фрахівця визначає його знання, уміння і досвід. Іншими словами, здатність мобілізувати теоретичні знання, практичні уміння і набутий досвіду конкретній особливій ситуації характеризує компетентність професійно успішного військового фрахівця [11]. Такий підхід є досить обґрунтованим.

Основними проявами розвиненості професійної компетентності офріцерів IAЗ $€$ такі:

- наявність теоретичної та практичної здатності до спеціальної діяльності;

- готовність до постійного саморозвитку та самовдосконалення у фаховій роботі;

- здатність до рефрлексії до саморефлексії;

- сорормованість відповідних професіонально важливих якостей як фрахівця, що фрормують індивідуальний стиль професійної діяльності тощо.

Профресійна освіта в такому випадку виступає засобом формування та розвитку компетентної діяльності, а готовність стає одним із важливих результатів якості підготовленості, що реалізується та перевіряється у фаховій діяльності.

Профресійна компетентність по суті містить, на думку науковців, великий потенціал кожного фахівця, який безпосередньо актуалізується та проявляється в його спеціальній діяльності [12, с. 28-34]. О. Євсюков зміст профресійної компетентності офріцерів визначає через цілі, завдання і характер військової праці, їх відповідністю соціальним замовленням суспільства. Вагому роль відіграє, на його думку, поєднання в завданнях різноманітних складових, які відображають поліфункціональність військової праці, що залежить від інтегративного характеру результату, який планується отримати. Фахова компетентність включає «профресійно-особистісну, соціально значущу якісну характеристику офіцера, його інтегративні властивості, що орієнтовані на неперервне самовдосконалення, самоосвіту» [13].
Фахову компетентність розуміють як складне інтегроване інтелектуальне, спеціальне та особистісне утворення, яке фрормується «у процесі профресійної підготовки у ВВН3, виявляється, розвивається і вдосконалюється у процесі військовопрофесійної діяльності, а ефективність його здійснення суттєво залежить від видів його теоретичної, практичної та психологічної підготовки до неї, особистісних, профресійних і індивідуальнопсихічних якостей, сприйняття цілей, цінностей, змісту та особливостей цієї діяльності» [14, с. 3-8].

Таким чином, рівень сорормованості/розвиненості професійної компетентності офріцерів інформаційно-аналітичного забезпечення можна виявити через результативність актуалізації ними військово-професійних і фрахових знань, умінь, прояв ціннісних орієнтирів, психічних механізмів саморегуляції у військово-профресійній діяльності. Тоді ситуації щодо розвитку механізмів самоуправління, саморегуляції виступають чинником, який визначає успішне фрормування/розвиток усіх компонентів професійної компетентності, що стимулюють компетентну поведінку суб'єкта діяльності. Відповідно професійну компетентність офріцерів IAЗ оперативно-тактичного рівня можна розуміти як його інтегроване професійно важливе утворення, що поєднує в собі його підготовленість, здатність і готовність мобілізувати та застосовувати військово-професійні та фрахові знання, уміння, навички, професійно важливі якості в професійній діяльності, що визначає успіх і водночас відповідальність за її результати.

Наступний важливий аспект - взаємозв'язок профресійної компетентності та профресіоналізму фахівця, що безпосередньо стосується офріцерів ІАЗ. Погляд на професійну компетентність як складову професіоналізму у військовій сорері був запропонований американськими науковцями, які розкривають зміст даного феномена через взаємозв'язок відданості справі, відповідальності та компетентності [8]. Проведений аналіз наукових досліджень дає змогу розглядати поняття «профресійної компетентності» вужче, ніж «просресіоналізм». Профресійна компетентність $€$, з одного боку, головною складовою професіоналізму фрахівця, а $з$ іншого - важливою умовою становлення профресіонала [15]. Тобто військовий професіонал має компетентно вирішувати професійні завдання у конкретних умовах, умовах ворожої протидії і в ситуаціях невизначеності, які потребують відпрацювання нових алгоритмів дій, прояву вольових якостей для досягнення успіху.

У чому ж полягає сутність профресійної компетентності військових фрахівців? Найбільш точним, у контексті даного дослідження, є підхід до їі трактування, поданий В. Неїжмаком. Зокрема він розуміє професійну компетентність військового фрахівця як «фрундаментальну характеристику 
особистості військовослужбовця, що виявляється у високому рівні професіоналізму, здатності до виконання завдань і обов'язків 3 несення військової служби, особистісно-творчої діяльності, яка відзначається фрундаментальністю, багатофункціональністю, надпредметністю, міждисциплінарністю, багатовимірністю та вимагає інтелектуальних, автономних і рефлексивних дій» [16, с. 51].

С. Каплун у структурі професійної компетентності майбутніх офріцерів тилу виділяє такі складові:

- професійно-кваліфікаційні характеристики (високий і достатній рівні сорормованості професійних знань, умінь, навичок професійної діяльності; продуктивність професійної діяльності, апробована в ході практичних занять);

- соціально-статусні характеристики (соціальний статус офріцера в системі української держави (екстеріоризаційний ефект); соціальний статус офріцера в системі служб Збройних сил (інтеріоризаційний ефект));

- особистісні характеристики (профресійно значущі особистісні якості; профресійно значущі особливості характеру офріцера; висока мотивація до здійснення професійної діяльності та зростання рівня професіоналізму) [17, с.112].

Особливості професійної компетентності військового фахівця в широкому сенсі зумовлені метою, завданнями і результатами військово-професійної діяльності, зокрема такими: екстремальним її характером; різноманітністю її складових, які визначаються іїі поліфункціональністю; інтегрованим характером результатів військової праці, що складається з боєготовності підрозділів (частин), морально-психологічного стану особового складу; відповідністю професійно важливих якостей і дій військовослужбовця до висунутих цілей, завдань і функцій його діяльності.

Отже профресійна компетентність офріцерів IA3, з одного боку, передбачає насамперед його здатність успішно реалізовувати посадові компетенції та досягати при цьому суттєвих позитивних результатів, а 3 іншого - характеризує позитивний результат фрункціонування системи військової освіти. Без сформованості професійної компетентності він не може стати суб'єктом військово-профресійної діяльності. Вона $є$ мобільною, гнучкою, інтегрованою і міжпредметно важливою характеристикою офіцера інфрормаційно-аналітичного забезпечення.

Таким чином, на основі розгляду психологопедагогічної літератури було вивчено основоположні дефініції дослідження понять «профресійна компетентність» і «професійна компетентність ооріцера |АЗ» на науково-теоретичному рівні на підставі ґрунтовного дедуктивного аналізу різних наукових підходів до їх трактування. У процесі дослідження опрацьовано різні трактування поняття «компетентність», які обумовлені:
- недостатнім усвідомленням смислу, змісту та вимог компетентнісного підходу до професійної підготовки фрахівців [18, с. 26-33], в тому числі і військових;

- недостатнім усвідомленням науковцями призначення системи професійної освіти та основного результату їі фрункціонування, яким має бути компетентний фрахівець, а не фрахівець із компетенціями [19, с.48-54];

- недостатнім розумінням дослідниками стандартної структури професійної діяльності різних фахівців та її психічного та психологічного аспекту.

Структура професійної компетентності офріцера IАЗ включає такі компоненти:

1) ціннісно-мотиваційний (цінності військової служби; ставлення до свого фраху; мотивація військово-професійної діяльності);

2) емоційно-вольовий (емоційно-вольова сорера психіки; стійкість до негативних чинників військово-професійної діяльності);

3) когнітивний (загальновійськові, військовопрофесійні та фрахові знання як офріцера-аналітика та офріцера-командира оперативно-тактичної ланки управління);

4) операційно-процесуальний: організаційний, управлінський, контрольно-корегувальний, педагогічний, комунікативний, методичний (організаційні, управлінські, контрольно-корегувальні, педагогічні, комунікативні, методичні навички, вміння та здатності);

5) менеджерський (менеджер оперативно-тактичної ланки управління);

6) психологічний чи фраховий (організатор виховного процесу підлеглих);

7) індивідуально-психічний (профресійно-важливі якості: витривалість, професійна мобільність, психічна стійкість, організованість, комунікативність, емпатія тощо);

8) суб'єктний (професійна суб'єктність, об'єктивна самооцінка, сприйняття самого себе як офріцера-командира-аналітика в оперативно-тактичній ланці управління).

Таким чином, по-перше, наявність цих компонентів забезпечує творчу реалізацію основних посадових компетенцій для офріцера оперативнотактичної ланки управління як для військового профресіонала та фрахівця в сорері аналізу інфрормації та добування нових знань. При цьому безпосередньо враховано такі їх службові фрункції:

- як офріцера - представника офріцерського корпусу;

- як менеджера середньої ланки управління у Збройних Силах України;

- як офріцера-вихователя для підлеглих - як фрахівця, який реалізує специфічні фрункції у військових підрозділах і частинах.

По-друге, вона ґрунтується на провідних ідеях і положеннях андрагогічного, контекстного, ком- 
петентнісного та суб'єктно-діяльнісного підходів, оскільки охоплює системно їх військово-професійну діяльність як суб'єктів управління і прийняття рішень, містить кожен елемент їх військово-професійної діяльності як менеджера оперативнотактичної ланки управління та фрахової діяльності як суб'єкта виховного процесу. Провідною вимогою контекстного підходу є те, що у процесі професійної підготовки офріцерів мають врахуватися цілі, сенси, зміст, методи, форми, засоби та результати їх військово-профресійної діяльності, тобто слід обов'язково врахувати цілі, зміст, екстремальний характер і результати насамперед бойової діяльності військових підрозділів і частин.

По-третє, ця організація охоплює всі структурні одиниці їх військово-професійної діяльності від визначення її цінностей і до самооцінювання результатів як творчого суб'єкта цієї діяльності, тобто обґрунтована 3 урахуванням основних положень теорії діяльності та діяльнісного підходу в профресійній психології та педагогіці. У зв'язку 3 цим основними компонентами професійної компетентності офріцерів ІАЗ мають бути основні компоненти діяльності. Зокрема цінності, мотивація, зміст, методи, прийоми, засоби, результати їх профресійної діяльності.

Відповідно, основною місією НУОУ щодо майбутніх офріцерів ІАЗ $€$ розвиток їх професійної компетентності як складного та багатовимірного психолого-педагогічного явища - професійно важливого утворення, стимулювання та забезпечення самосприйняття ними самих себе як суб'єктів оперативно-тактичної ланки управління та офріцерів IАЗ у ЗС України.

Висновки. Актуальність проблеми впровадження компетентнісного підходу до визначення якості професійної підготовки офіцерів IАЗ і забезпечення цілеспрямованого розвитку їх профресійної компетентності на етапі оперативно-тактичного рівня підготовки у НУОУ є безперечною та в науковому аспекті - перспективною.

В результаті проведеного аналізу визначено багатоаспектність і неоднозначність поняття «професійна компетентність офріцера ІАЗ», суть якого залежить від цілей, змісту та специфіки його профресійної діяльності.

3'ясовано, що профресійна компетентність офріцера ІАЗ включає такі компоненти: ціннісно-мотиваційний, емоційно-вольовий, когнітивний, операційно-процесуальний, психологічний чи фраховий, профресійно-важливі якості чи індивідуально-психічний, суб'єктний.

Перспективні напрями подальших досліджень: зміст і структура професійної компетентності офріцерів ІАЗ оперативно-тактичної ланки управління.

\section{БІБЛІОГРАФІЧНИЙ СПИСОК:}

1. Ягупов В. Педагогіка : навчальний посібник. Київ : Либідь, 2002. 560 с.

2. Гончаренко С. Профресійна освіта: словник : навч. посіб. / уклад. С. Гончаренко та ін. ; за ред. Н. Ничкало. Київ : Вища школа, 2000. 149 с.

3. Овчарук О. Розвиток компетентнісного підходу : стратегічні орієнтири міжнародної спільноти. Компетентнісний підхід у сучасній освіті : світовий досвід та українські перспективи : бібліотека освітньої політики. Київ : К.І.С., 2004. С. 6-15.

4. Педагогічні технології у безперервній профресійній освіті : монографрія / С. Сисоєва та ін. ; за ред. С. Сисоєвої. Київ : ВІПОЛ, 2001. 502 с.

5. Vuono C. Professionalism and the Army of the 1990-s. Military Review. 1990. № 4. 297 p.

6. Velde C. Crossing borders: an alternative conception of competence. Annual SCUTREA conference. New York : Queen's University Belfast, 1997. P. 27-35.

7. Равен Дж. Педагогическое тестирование : проблемы, заблуждения, перспективы / пер. с англ. Москва : Когито-Центр, 1999. 44 с.

8. Sam S. Sarkesian. Changin dimensions of military professionalism. Military Review. 1979. № 3. 59 p.

9. Свистун В. Полікультурна компетентність військовослужбовця як суб'єкта діяльності 3 підтримання міжнародного миру і безпеки. Проблеми освіти. 2019. Вип. 92. С. 154-158.

10. Ягупов В. Методологічні основи розуміння та обґрунтування понять «компетентність» і «компетенція». Нові технології навчання. Київ-Вінниця, 2011. Вип. № 69, ч. 1. С. 3.

11. Торічний О. Теоретико-методичні засади фрормування військово-спеціальної компетентності майбутніх офріцерів-прикордонників у процесі навчання : дис. ... док. пед. наук : 13.00.02. Хмельницький, 2013. 605 C.

12. Ягупов В. Компетентнісний підхід до професійної підготовки майбутніх фрахівців у системі професійно-технічної освіти. Креативна педагогіка. 2011. Вип. 4. С. 28-34.

13. Євсюков О. Педагогічні умови формування профресійної компетентності майбутніх офріцерів у навчальному процесі вищого військового навчального закладу : дис. ... канд. пед. наук : 13.00.04; Харківський нац. пед. ун-т ім. Г.С. Сковороди. Харків, 2006. 172 c.

14. Ягупов В., Свистун В. Компетентнісний підхід до підготовки фрахівців у системі вищої освіти. Наукові записки НаУКМА. Том 71. Педагогічні, психологічні науки та соціальна робота : збірник наукових праць / гол. ред. Гірник А. Київ, 2007. С. 3-8.

15. Ягупов В. Компетентнісний підхід у профресійній підготовці фрахівців у системі професійно-технічної освіти. Педагогічна і психологічна науки в Україні : збірник наукових праць : в 5 т. Київ : Педагогічна думка, 2012. Т. 4 : Професійна освіта і освіта дорослих. С. 124-134.

16. Неижмак В. Формирование профессиональной компетентности выпускника высшего военного учеб- 
ного заведения (на примере общепрофессиональных дисциплин) : дисс. ... канд. пед. наук : 13.00.08. Ульяновск : Изд-во УлГПУ, 2004. 205 с.

17. Каплун С. Професійна компетентність майбутнього офріцера служб тилу як об'єкт наукового аналізу. Вісник Житомирського державного університету імені Івана Франка. Житомир, 2008. Вип. 42. С. 111-115.

18. Ягупов В. Становление понятийно-терминологического аппарата компетентностного подхода к профрессиональному образованию. Науковий вісник Інституту профресійно-технічної освіти НАПН України. Київ : Інститут професійно-технічної освіти НАПН України, 2013. № 6. С. 26-33.

19. Ягупов В. Компетентностный подход к профессиональному образованию. Отечественная u зарубежная педагогика. № 2 (5). 2012. C. 48-54. URL: LIBRARY.RSU.EDU.RU'BLOG/ WP-CONTENT...2013/09/IZ_RAO...(дата звернення: 09.01.2020). 